\title{
混凝土施工技术在水利水电工程施工中的应用
}

刘章

山东云尚建设项目管理有限公司

DOI:10.32629/hwr.v4i6.3120

[ 摘 要] 水利水电工程是我国基础设施建设中的重要组成部分, 混凝土是水利水电工程建设中常用的基础建筑材料,且在工程建设中有十分重 要的作用, 合理合规应用混凝土施工技术, 可以从整体上提高水利水电工程的质量。

[关键词] 混凝土施工技术; 水利水电工程; 应用

混凝土施工技术的应用, 对于水利水电工程的质量提高有着关键性作 用, 不过, 随着我国现代化建设进程的加快, 水利水电工程设计、施工也在 随之发展, 如果不按照水利水电工程要求的标准应用混凝土施工技术, 将 会对工程的整体建设产生负面影响, 因此, 在水利水电工程建设中应用混 凝土施工技术时, 一定要对施工环境、标准进行全方位的实地考察, 以此保 证混凝土施工技术的应用, 有效提高水利水电的建设质量。

\section{1 混凝土施工技术在水利水电工程建设中的重要性}

混凝土是工程建设中的常见材料, 是采用各种建筑骨料、凝胶材料以 及水根据不同要求按照一定比例摚拌而成的人工建筑材料, 在水利水电 工程的具体建设过程中, 混凝土施工技术的应用主要由四部分组成, 分 别是混凝土的搅拌、运输、浇筑和养护。由于水利水电工程建设面积比 较大, 而且建设成本高, 为了保障工程建设的牢固性, 这就需要在工程的 实际建设过程中应用混凝土施工技术 ${ }^{[1]}$, 因为混凝土原材料丰富、造价 成本低、耐腐蚀性较好, 而且在施工过程中的操作比较简单, 在水利水电 工程建设中应用混凝土施工技术, 在一定程度上降低了工程建设的成本, 提高了工程的耐腐蚀性, 此外, 混凝土材料拥有较强的刚度, 能够延长水利 水电工程的使用周期。所以, 混凝土施工技术在水利水电工程建设中, 作用 相当重要。

\section{2 混凝土施工技术在水利水电工程中的实际应用}

2. 1 混凝土施工技术在水闸建设中的应用

水闸建设在水利水电工程的施工建设中是非常重要的, 水闸是否坚固 直接影响到整个工程的建设和工程的完工后的使用, 水闸建设方式根据工 程的的整体坏境来看主要有两种, 一种是开敞式水闸建设, 适用于建设坏 境宽敞的水利水电工程, 另一种是涵洞式水闸建设, 主要适用于建设环境 较为狭窄的工程。混凝土施工技术在水闸建设中主要应用于浇筑水闸底板 和水闸闸墩, 在对水闸底板进行混凝土浇筑时, 一般要先在基面上铺一层 厚度约为 10 厘米的混凝土垫层, 垫层是为了保护闸基土不受扰动, 浇筑前, 要仔细确认底板钢筋的分布状态与分布距离, 此外, 还要对混凝土的整体 强度进行检验, 确保其基底坚固性。

在浇筑闸墩时, 先将模板内侧以和闸墩底面用压力水进行清洗, 经过 清洗后, 从底层模板上的预留孔会将污水排出, 然后将小孔堵住, 开始浇筑 工作, 在施工过程中, 对于混凝土的上升速度一定要掌握好, 防止流态混凝 土量增加过大, 对底层模板产生较大的侧向压力, 开敞式水闸闸墩为了避 免工程后续产生质量问题, 可以考虑采用滑模施工。

2. 2 混凝土施工技术在大坝建设的应用

在水利水电工程建设中, 由于大坝的建设规模较大, 需要经过多个阶
段建设完成, 分缝分块技术和接缝灌浆技术是大坝建设中常用的施工方 式。大坝坝体的大规模导致其对混凝土需求量较多, 一次性浇筑很难满足 实际建设需求, 所以要采用分缝分块施工技术, 这样保证大坝的施工质量 的同时也稳定了大坝的整体结构, 在混凝土的浇筑过程中, 要顺应施工现 场的钢筋走向和高度, 另外, 还有一种浇筑方式, 对于面积大且较长的水坝 建设比较适用, 叫做通仓分块浇筑, 在通仓分块浇筑过程中, 机械设备使用 率非常高, 施工时间非常快 ${ }^{[2]}$ 。

接缝灌浆施工技术在水利水电工程建设中, 是非常重要而且隐蔽的工 作, 在竣工后的工程验收中, 几乎无法对其进行质量检测, 因此, 这项工作 对于工人的施工技术和工艺要求极高, 而且, 在工作过程中, 工人必须按照 既定的顺序进行接缝灌浆, 这样才能保证施工后大坝的完整性。

2. 3混凝土施工技术在工程养护中的应用

完成混凝土浇筑工作后, 还有一个非常重要环节, 就是混凝土养护, 混 凝土养护有特定的规定和要求, 如果施工季节是夏季, 要选用能自动喷水 的旋转式喷头进行浇筑仓面的养护, 并且要控制每部酒水器的出水量在 每分钟 $12 \sim 16 \mathrm{~L}$, 酒水器酒不到的地方, 要安排专业人员完成浇筑仓面的 养护工作, 对于纵横缝以及上下游等相对隐蔽的位置, 要用钻有小孔的 塑料管进行养护工作, 一般情况下, 在塑料管表面每隔 $20 \sim 30 \mathrm{~cm}$ 钻一个 小孔就可以。

如果在冬季进行施工, 除了注意给浇筑仓面保温以外, 也需要对其进 行酒水养护, 主要是为了保持混凝土表面的湿度, 可以持续保持在标准范 围内 ${ }^{[3]}$ 。

\section{3 总结}

在当今的社会主义建设时期, 我国对于水利水电工程的发展极为重视, 对工程建设的质量要求也越发严格, 混凝土作为水利水电工程必不可少的 建筑材料, 在整个工程建设当中有着极为重要的地位, 因此, 想要使我国水 利水电工程的发展水平得到提升, 必须要在工程的实际施工过程中, 按照 相应的标准来使用混凝土施工技术。

[参考文献]

[1]田华莲.混凝土施工技术在水利水电工程施工中的应用 [J].大科 技,2019,(07):107-108.

[2]梁志杰.混凝土施工技术在水利水电工程施工中的应用 [ J ] 南方农 机,2018,49(20):105.

[3]纪耀东.混凝土施工技术在水利水电工程施工中的应用 [J]. 建筑工 程技术与设计,2018,(07):1537. 